\title{
REGIÕES MORFOLÓGICAS: UMA LEITURA BIDIMENSIONAL DO PLANO DA ÁREA CENTRAL DA CIDADE DE FLORIANÓPOLISISC/BRASIL
}

\author{
Anicoli Romanini \\ Adriana Marques Rossetto \\ Universidade Federal de Santa Catarina \\ Universidade Federal de Santa Catarina \\ anicoliromanini@yahoo.com.br \\ amarquesrossetto@gmail.com
}

\section{RESUMO}

Os processos de transformações do território estão diretamente relacionados ao estabelecimento do traçado das cidades. Assim, estudos da morfologia urbana promovem a leitura das cidades por meio das suas características físicas e espaciais, juntamente com a indicação dos atores e dos processos responsáveis por esse processo. Dessa forma, as regiões morfológicas representam diferentes áreas da cidade, que possuem, em determinado momento, características físicas relacionadas à forma (tipo de plano, de tecido edificado), que as distinguem das demais áreas envolventes. Logo, busca-se com este trabalho, apresentar as regiões morfológicas identificadas na estrutura urbana da área central de Florianópolis, cidade localizada ao Sul do Brasil, no Estado de Santa Catarina. A leitura bidimensional do plano da cidade, baseada em metodologia proposta por Conzen, seu processo evolutivo, possibilitou a identificação de regiões morfológicas, a partir dos seus elementos originais e sua evolução, durante diferentes períodos temporais.

Palavras-chave: Produção do espaço urbano, Morfologia urbana, Regiões morfológicas.

\begin{abstract}
The processes of transformation of the territory are directly related to the establishment of the layout of the cities. Thus, studies of urban morphology promote the reading of cities through their physical and spatial characteristics, together with the indication of the actors and the processes responsible for this process. In this way, the morphological regions represent different areas of the city, which possess, at a given moment, physical characteristics related to the form (type of plan, of fabric built), which distinguish them from the surrounding areas. Therefore, the aim of this work is to present the morphological regions identified in the urban structure of Florianópolis, a city located in southern Brazil, in the State of Santa Catarina. From the two - dimensional reading of the city plan, defined by Conzen, the evolutionary process was interpreted, which allowed the identification of the morphological regions, from their original elements and their evolution, during different time periods.
\end{abstract}

Key words: Urban space production, Urban morphology, Morphological regions. 


\section{INTRODUÇÃO}

O espaço urbano é o ambiente onde acontecem as relações sociais advindas da urbanização das cidades. Neste sentido, se faz necessário compreendê-lo enquanto forma, processo e função. A partir destas relações, uma abordagem morfológica adequada deve considerar a avaliação física do local, mas também "as questões sociais e econômicas relevantes ao seu desenvolvimento. Estas vão proporcionar as bases para a interdependência do plano, do tecido urbano e do uso do solo, como também as fontes das abordagens funcionais e morfológicas." (Costa e Netto, 2015, p.52).

Isso porque, a análise da produção do espaço urbano a partir do estudo da morfologia urbana promove a leitura das cidade por meio das suas características físicas e espaciais, juntamente com a indicação dos atores e dos processos responsáveis pela sua transformação.

A morfologia urbana começou a tomar forma como um campo de conhecimento no final do século XIX, com os trabalhos desenvolvidos pelo geógrafo alemão, Otto Schlüter, considerado "o pai da morfologia urbana." (Whitehand, 2007). E em meados do século XX, o geógrafo M. R. G. Conzen, passa a atuar como um dos principais promotores da abordagem histórico-geográfica do período, ao apresentar duas abordagens, formal e temporal, e demonstrar que é possível identificar como os reflexos da ação da sociedade atuam na paisagem.

Conzen (2004) apud Costa e Netto (2015, p.34) refere-se à paisagem como produto, "na qual as dinâmicas sociais ao longo do tempo tornam-se os elementos condicionadores da forma da paisagem urbana". Alinhado a este preceito e considerando os colocados por Santos (2014), defende-se a organização do espaço pela dimensão histórica ou temporal, pois entende-se que: "O comportamento do novo sistema está condicionado pelo anterior. Alguns elementos cedem lugar, completa ou parcial mente, a outros da mesma classe, porém mais moderno; outros elementos resistem à modernização; em muitos casos, elementos de diferentes períodos coexistem. Alguns elementos podem desaparecer completamente sem sucessor e elementos completamente novos podem se estabelecer. O espaço, considerado como mosaico de elementos de diferentes eras, sintetiza, de um lado, a evolução da sociedade e explica, de outro lado, situações que se apresentam na atualidade." (Santos, 2014, p.36).

Nesse sentido, é importante considerar nas análises relacionadas ao processo de produção do espaço urbano, as análises temporais dos processos de construção dessa organização. Entende-se, pois, que o

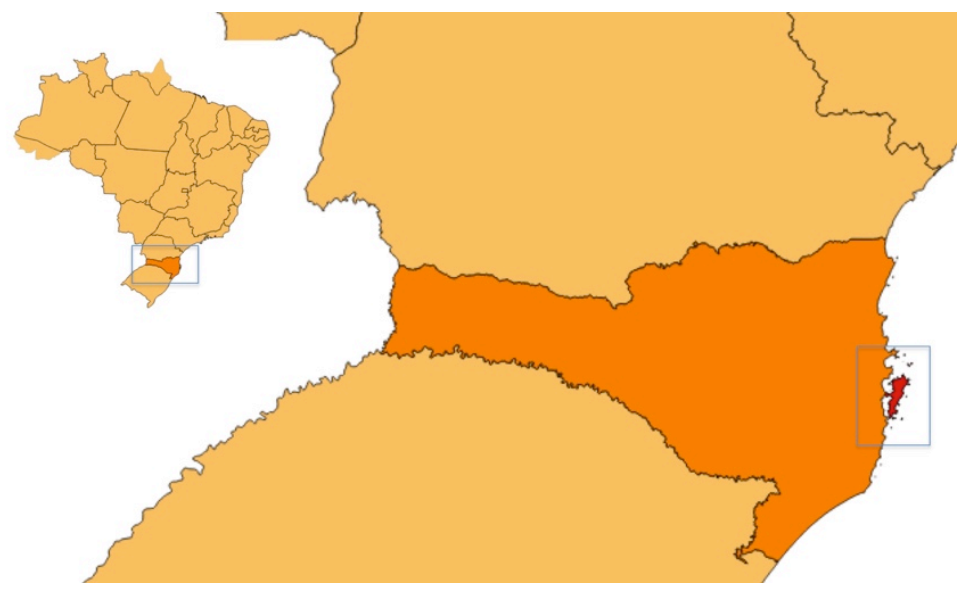

Figura 01. Localização de Florianópolis.

(Autoras, 2018). "movimento histórico do processo de produção espacial que desvenda o fato de que o espaço geográfico não é nem eterno, nem inerte e imóvel, e tampouco natural, mas um produto concreto de relações sociais historicamente determinadas." (Carlos, 1994, p.33).

Logo, apresentar as regiões morfológicas identificadas na estrutura urbana de Florianópolis, cidade localizada ao Sul do Brasil, no Estado de Santa Catarina (Figura 01), é o objetivo deste trabalho, que busca a partir da leitura bidimensional do plano ${ }^{1}$ da cidade, baseada em metodologia proposta por Conzen, fazer a interpretação do seu processo evolutivo.

\section{METODOLOGIA}

\footnotetext{
${ }^{1}$ Ou planta de cidade - ao se referir em leitura do "plano" urbano da cidade, está-se referindo a leitura da planta da cidade, do seu traçado urbano - tecido urbano.
} 
A metodologia possibilitou a identificação das regiões morfológicas, a partir dos seus elementos originais e sua evolução, durante diferentes períodos temporais, que combinadas entre si, possibilitaram avaliar as transformações morfológicas ocorridas na área central da cidade de Florianópolis.

As análises foram desenvolvidas a partir da leitura das ortofotos ${ }^{2}$ históricas (Figuras 02 e 03) disponíveis gratuitamente no site do Geoprocessamento Corporativo da Prefeitura Municipal de Florianópolis (PMF-GEO, 2017) referentes aos anos de 1938, 1957, 1977, 1994 e 2002. Estes anos foram selecionados em função das suas disponibilidades nos arquivos digitais da PMF, através do site do Geoprocessamento Corporativo. As informações retiradas das imagens foram compiladas em arquivos de Geoprocessamento - no software QGIS.

Para cada período definido nas análises, foi possível identificar as transformações físicas ocorridas a partir das leituras bidimensionais do plano da cidade de Florianópolis (região insular), através do sistema viário e do parcelamento das quadras correspondentes.

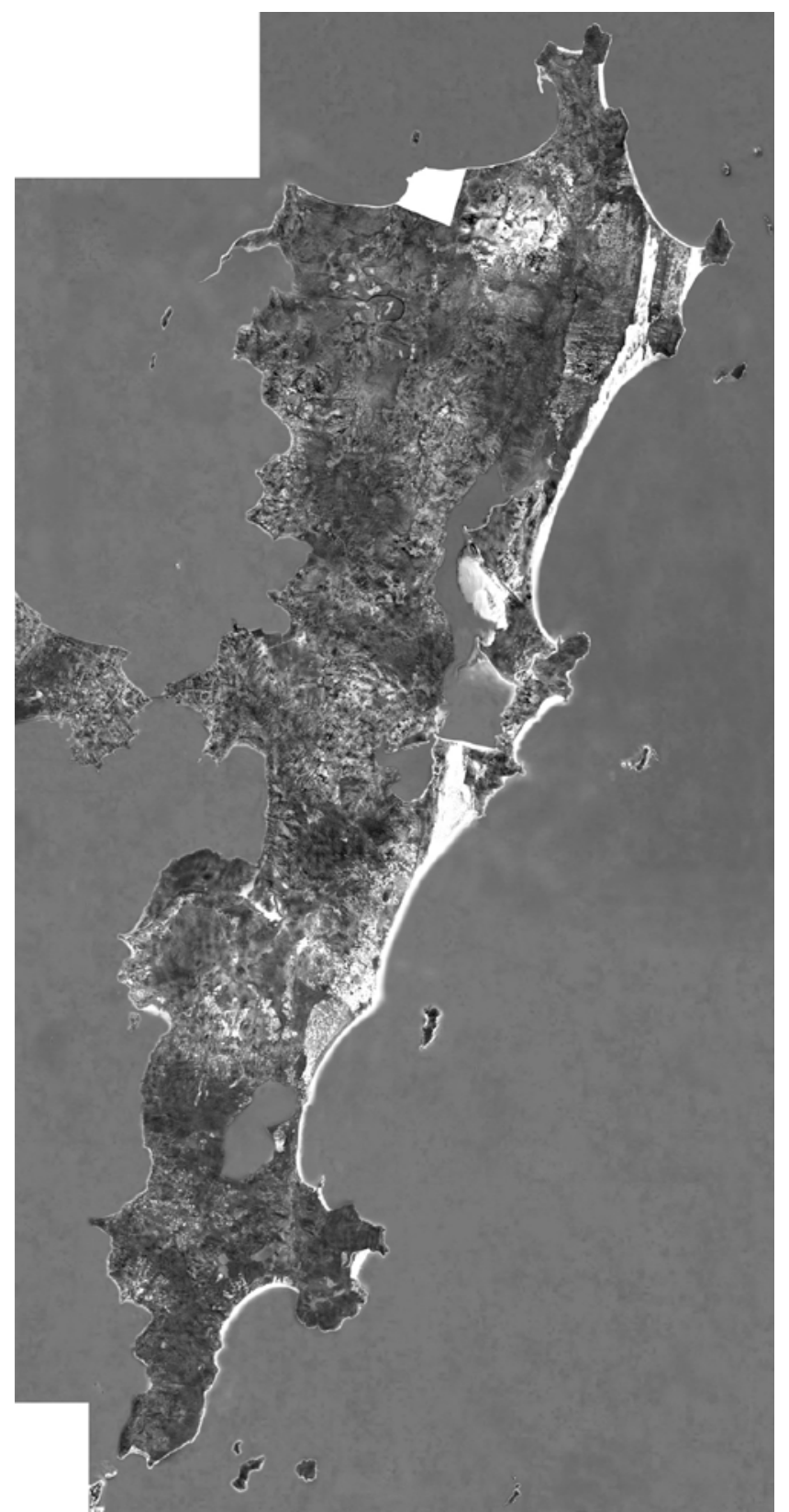

Figura 02. Ortofoto de Florianópolis - 1938. (Geoprocessamento - PMF, 2017).

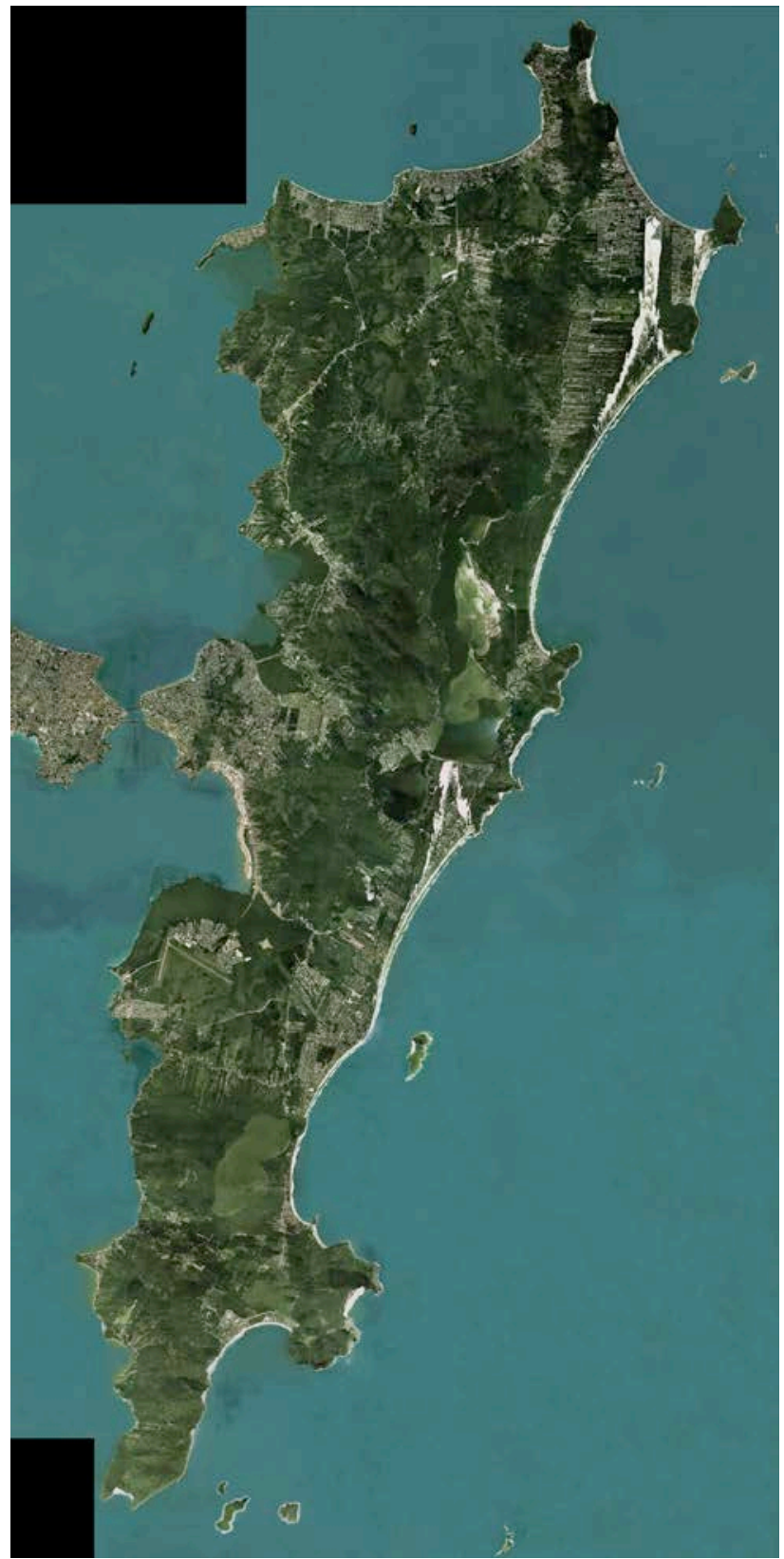

Figura 03. Ortofoto de Florianópolis - 2002. (Geoprocessamento - PMF, 2017).

\footnotetext{
${ }^{2}$ Uma ortofoto pode ser entendida como uma imagem fotográfica que passou por processos computacionais, nos quais foram eliminados o deslocamento em relação ao relevo e a distorção de geometria. Estas, podem ser utilizadas para auxiliar o usuário em localizações e análises espaciais (Geoprocessamento PMF, 2017).
} 
As ortofotos utilizadas nas análises da produção do espaço urbano e suas respectivas escalas, foram as seguintes (Tabela 01):

\begin{tabular}{|l|l|}
\hline ANO & ESCALA \\
\hline 1938 & $1: 35000$ \\
\hline 1957 & $1: 35000$ \\
\hline 1977 & $1: 35000$ \\
\hline
\end{tabular}

\begin{tabular}{|c|c|}
\hline ANO & ESCALA \\
\hline 1994 & $1: 35000$ \\
\hline 2002 & $1: 5000$ \\
\hline
\end{tabular}

Tabela 01. Ortofotos disponíveis.

(Geoprocessamento - PMF, 2017).

Optou-se pelo uso da cartografia digital, em função da possibilidade de integração que essa técnica apresenta, juntamente à possibilidade de "amarração das informações contidas em um banco de dados que, por sua, deve apresentar uma estruturação espacial definida [...]" (Fitz, 2008, p.108). E com as leituras das ortofotos ou fotografias digitais, é possível fazer o resgate histórico do processo de produção do espaço urbano de Florianópolis, devido à quantidade de informações que estas imagens contém.

\section{FORMA URBANA E REGIÕES MORFOLÓGICAS}

Nas análises da forma urbana, os estudos da morfologia urbana se apresentam como importantes meios de entendimento dos processos de produção do espaço urbano, pois estas consideram "la combinación de fenómenos en la superficie terrestre se traduciría en diferentes tipos de paisajes, de morfologías territoriales." (Capel, 2002, p.19). Nestas combinações, a morfologia urbana se apresenta como "[...]o sentido da articulação entre as formas, os processos e as lógicas que ensejam as dinâmicas de estruturação, segundo as quais podemos compreender essas relações." (Sposito, 2016, p.137).

O sentido estritamente morfológico, se concentra na diversificação das formas visíveis na configuração da paisagem urbana, através do plano urbanístico e do uso e ocupação do solo, juntamente com às transformações ocorridas ao longo do tempo. O aspecto dinâmico da sociedade, produz e altera a paisagem urbana ao longo do tempo, através da compreensão dos mecanismos que refletem a sociedade urbana local.

Por isso, a interpretação do processo evolutivo, através da análise dos elementos originais e de sua evolução, durante períodos temporais, geram períodos morfológicos possíveis de serem identificados nas formas materiais, que por sua vez indicam os reflexos das ações econômicas e sociais em que foram desenvolvidos.

Através de duas abordagens, formal (primeira) e temporal (segunda), em que os reflexos da ação da sociedade atuam na paisagem, Conzen (2004) apud Costa e Netto $(2015$, p.34) refere-se a paisagem como produto, "na qual as dinâmicas sociais ao longo do tempo tornam-se os elementos condicionadores da forma da paisagem urbana". Com isso, a partir da análise do sistema viário, quadras, lotes e a edificação, é possível avaliar as transformações morfológicas ocorridas no meio urbano, em diferentes períodos temporais (Figura 04).

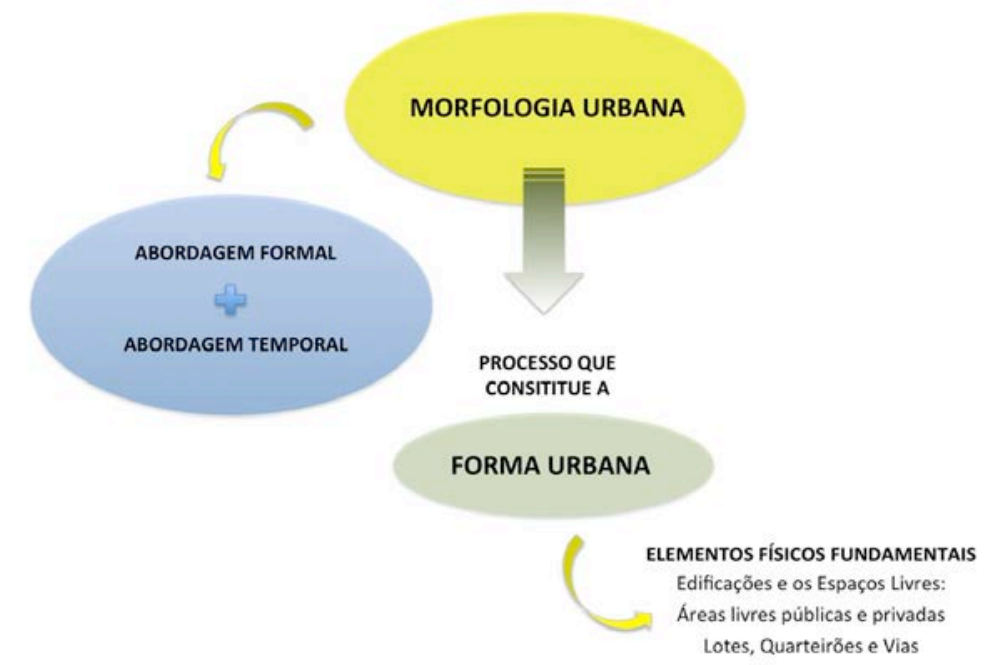

Figura 04. Abordagens morfológicas - Conzen. 
(Autoras, 2017)

Em 1960, em um estudo desenvolvido em Alnwick, cidade localizada ao norte de Northumberland (Inglaterra), Conzen inicia um dos principais estudos da área da morfologia urbana, em que apresenta de forma minuciosa a análise morfológica do plano urbano, destacando primeiramente o arranjo viário e logo após o padrão das edificações semelhantes que formam uma unidade tipológica (Figura 05).

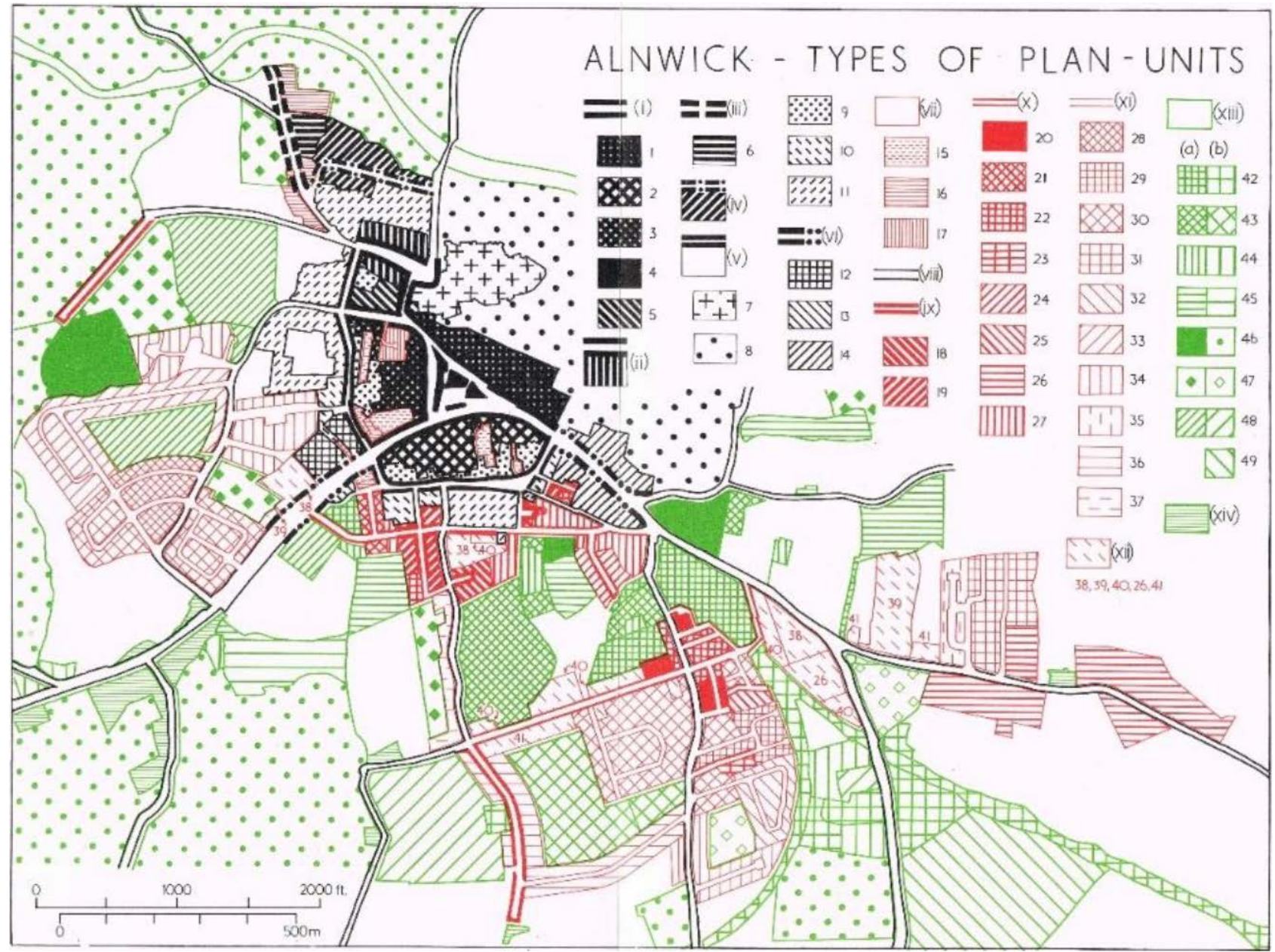

Figura 05. Alnwick, Northumberland - tipos de unidades de plano.

(Conzen, 1960).

Conzen "identificou uma hierarquia de quatro ordens de regiões baseadas principalmente no plano de cidade (uma leitura bidimensional)" (Oliveira, 2016, p.66). Além destes, Conzen "[...] chama a atenção sobre o papel do contexto físico da ação humana na formação, desenvolvimento e transformação do plano urbano e explica que, sem essa percepção, os planos tornam-se incompreensíveis." (Costa e Netto, 2015, p.52). Com este mapeamento, o pesquisador apresenta os períodos morfológicos de cada época levantada, e verifica de forma ocorreram as transformações nas formas edificadas, e com isso, o padrão de crescimento urbano da cidade. Por último "são apresentados os tipos de unidades de planejamento e a estrutura geográfica da paisagem urbana de Alnwick". (Costa e Netto, 2015, p.52).

De forma resumida, as principais qualidades do estudo da cidade de Alnwick referem-se: à formação de uma estrutura básica dos princípios da morfologia; à adoção de uma abordagem técnica; à escolha do lote urbano como ponto cartográfico fundamental da análise morfológica; à adoção de uma análise cartográfica detalhada, em várias escalas de alta resolução, precisa, conjugadas com os trabalhos de campo, e documentadas por fotos; e por último, à constatação de que esses resultados refletidos na paisagem urbana são resultantes dos conceitos germânicos de onde provêm.

"Outro aspeto fundamental na obra de Conzen é o desenvolvimento de conceitos sobre o processo de desenvolvimento urbano [...]: cintura periférica, região morfológica e ciclo de parcela burguesa." (Oliveira, 2016, p.65). 
Na cintura periférica ou fringe-belt, segundo Whitehand (2007, p.ii-04): "O modelo enfatiza o grão histórico da cidade, especialmente as zonas muito diferentes que tendem a ser criadas durante os períodos em que 0 crescimento externo da área residencial foi contido devido a uma queda na construção das residências ou por algum outro obstáculo ao desenvolvimento residencial, como uma barreira física. As cinturas periféricas não são apenas relevantes para a compreensão da estrutura morfológica das cidades, mas também são pertinentes para o planejamento urbano. Para apreciar o seu completo significado, elas precisam ser vistas em relação a um quadro mais amplo das relações, incluindo ciclos de construção, valores de terra e adoção de inovações. Uma vez que a estrutura da cidade é entendida nesses termos histórico-geográficos, torna-se evidente a relevância da apreciação das variações de algumas características básicas no nosso meio ambiente, como a densidade e o padrão de estradas, a quantidade de vegetação, as construções cobertas e os tamanhos e as formas de parcelas."

Em síntese, "uma cintura periférica tende a formar-se na franja urbana durante um período em que a área construída não está a crescer ou que está a crescer muito lentamente." (Oliveira, 2018, p.19). Nestas estão incluídas, "áreas relativamente abiertas, a menudo con vegetación, como parques, campos de deportes, servicios públicos y tierras conectadas a varias instituciones." (Whitehand, 2007, ii-03).

A região morfológica segundo Oliveira (2016, p.66), "é uma área que tem uma unidade em relação à sua forma que a distingue das áreas envolventes.". E o ciclo da parcela burguesa ou burgage cycle é "o ciclo de vida de uma parcela que é propriedade de um burguês" (Oliveira, 2018, p.19).

Da mesma forma, ao investigar outros estudos, como o parcelamento e as modalidades de loteamento, remembramento e desmembramento, dos lotes burgueses, a investigação sobre as fringes belts e as regiões morfológicas, originam uma série de novas abordagens, de relevante importância para as pesquisas morfológicas.

Para Solá_Morales (1997, p.19), "La construcción de la ciudad es parcelación + urbanización + edificación. Pero estas tres operaciones no son actos simultáneos ni encadenados siempre de igual manera. Al contrário, de sus múltiples formas de combinarse en el tiempo y en el espacio, se origina la riqueza morfológica de las ciudades. Tanto mayor, cuanto más variadas sean las formas de esa combinatoria."

A partir de 1960, em um estudo sobre a cidade de Newcastle upon Tyne, Conzen consegue avançar nos aspectos relacionados às fringes belts, com a aplicação dos conceitos de expansão, consolidação e segregação funcional, em função da complexidade da malha existente. Segundo Oliveira (2018, p.19), "o contributo fundamental de Conzen foi integrar os padrões de cintura periférica de uma cidade numa teoria morfológica sobre as interações entre diferentes processos espaciais formativos e transformadores, conforme é evidenciado no registo cartográfico detalhado da evolução física de uma cidade."

"A excelência do trabalho efetuado em Alnwick e os estudos subsequentes, realizados em Newcastle upon Tyne, tornam-se referências essenciais para estudos de morfologia, que constitui seu legado que é desenvolvido por seus seguidores." (Costa e Netto, 2015, p.55). Neste sentido, entre os 10 conceitos $^{3}$ colocados por Costa e Netto (2015, p.56) que podem ser considerados como fundamentais para análise de processos espaciais formativos e transformadores na evolução das cidades e que alinham-se com as características do estudo aqui apresentado encontram-se: a historicidade como característica geral das paisagens urbanas; a análise do plano urbano; o processo morfológico; as fringe belts e a combinação dos processos morfológicos - unidades de planejamento.

Nas últimas décadas, posteriormente, mas a partir dos trabalhos desenvolvidos por Conzen, o professor Jeremy Whitehand vem coordenando o Urban Morphology Research Group (UMRG), da Escola de Geografia, Ciências da Terra e do Ambiente da Universidade de Birmingham. De acordo com (Costa e Netto, 2015, p.57), "a pesquisa do professor Whitehand sobre a forma urbana pode ser resumida em três categorias: o estudo da morfogenética urbana, a integração das concepções morforgenéticas e a economia das cidades, e o estudo dos agentes responsáveis pelo desenvolvimento da paisagem urbana." Além de fundamentar as bases conceituais da geografia territorial e futuramente da geografia urbana a partir da análise das "três formas sistemáticas que compreendem a paisagem cultural são os assentamentos, a ocupação do solo e os eixos

\footnotetext{
${ }^{3} \mathrm{~A}$ historicidade como característica geral das paisagens urbanas; a paisagem urbana como palimpsesto; a análise da paisagem urbana; a análise do plano urbano; o processo morfológico; as fringe belts; os lotes burgueses ou medievais; a combinação dos processos morfológicos - unidades de planejamento; os tipos funcionais e os regionais e; os atributos regionais.
} 
de comunicações". (Schlüter, 1899 apud Costa e Netto, 2015, p.42). Destas, a pesquisa se apoia no o estudo da morfogenética urbana e na integração das concepções morforgenéticas.

\section{AS REGIÕES MORFOLÓGICAS DA ÁREA INSULAR DE FLORIANÓPOLIS}

Florianópolis é uma província de colonização açoriana, que teve seu primeiro núcleo urbano implantado na Ilha de Santa Catarina, na Vila do Desterro (Figura 06), final do século XIX. Em função das atividades predominantes no início do século, pesca e a agricultura familiar, juntamente com as atividades portuárias de comércio-exportação e o transporte marítimo, a malha urbana estruturou-se com um núcleo central no Porto e no Mercado Público, em núcleos coloniais.

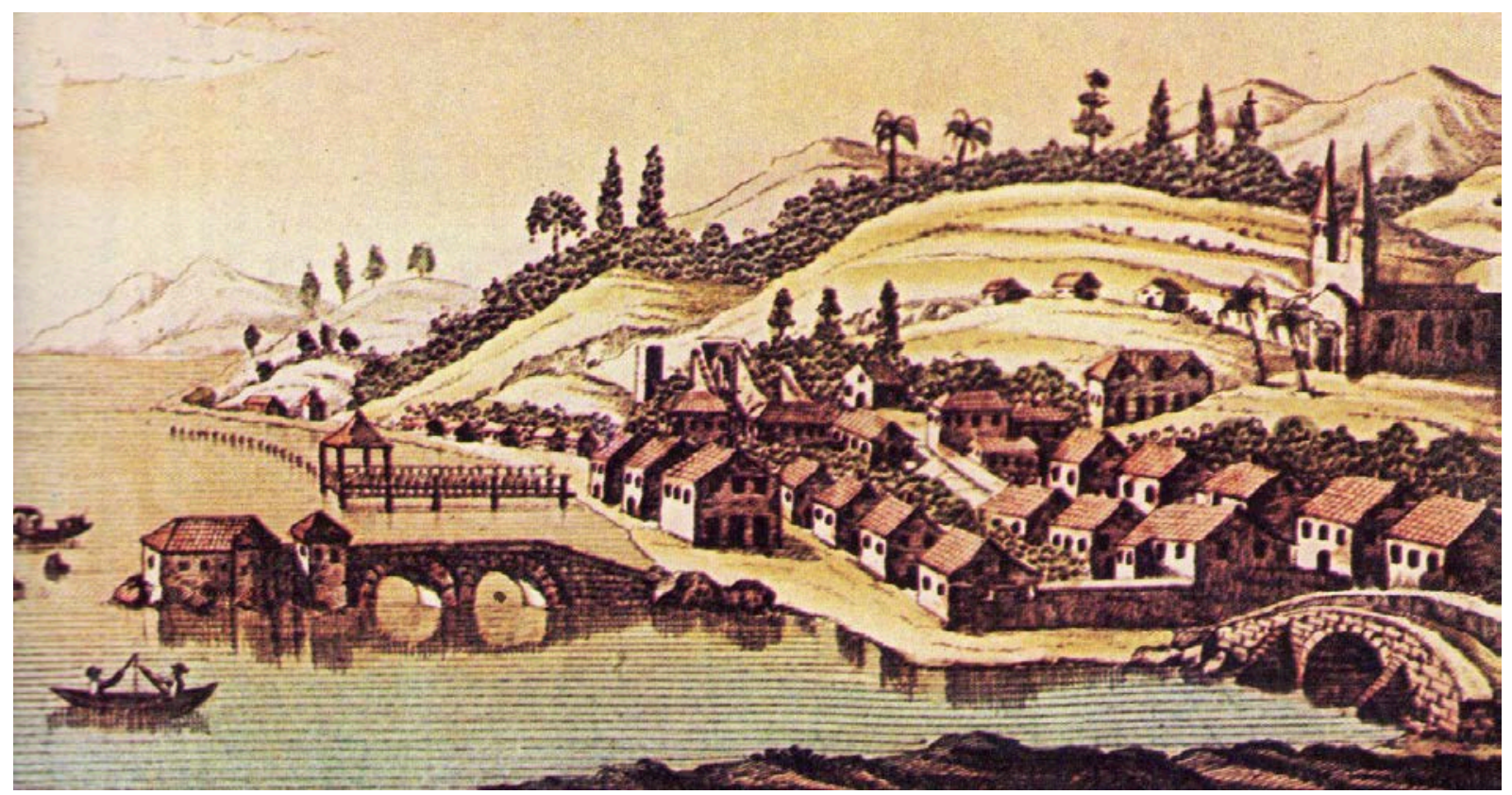

Figura 06. Vila de Desterro retratada pelo navegador Adam Von Krusenstern, em 1803.

(Menezes, 2011). 


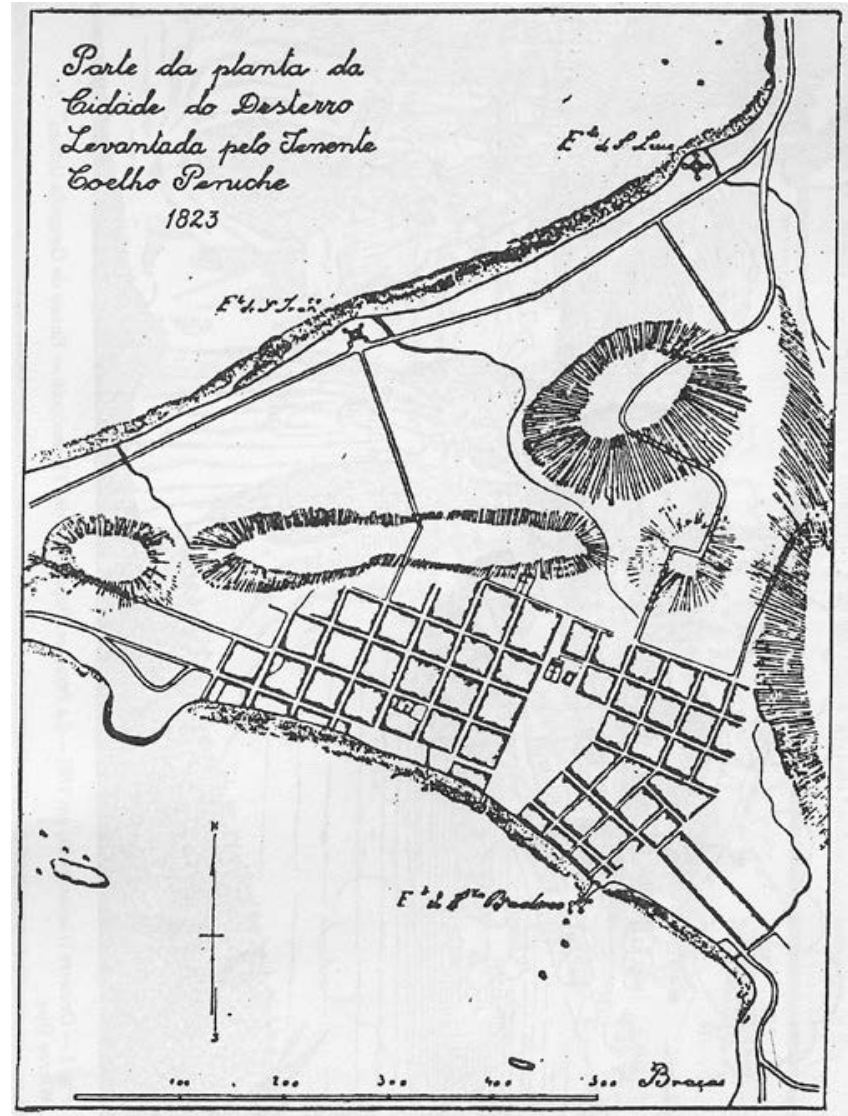

Figura 07. Planta de Desterro de 1823.

(Peluso Júnior, 1991).
Decorrente da influência colonial originária do século XIX, o processo histórico de ocupação do território insular ocorreu de maneira agrupada ao longo da costa litorânea. Dessa forma, o processo de crescimento e expansão do território urbano de Florianópolis é resultado de um traçado preexistente, originário em sua maior parte, do parcelamento de áreas agrícolas, caracterizadas por "pequenas propriedades longitudinais situadas de forma perpendicular aos caminhos." (Reis, 2012, p.127).

Este parcelamento, influenciou o traçado das ruas de forma definitiva, como se observa na Figura 07, e conforme relato de Saint-Hilarie (1936, p.153): "A cidade é dividida em duas partes desiguais por uma grande praça que ocupa quase toda sua largura e se estende, em suave declive, até a praia. Essa praça tem a forma de um quadrilongo, é gramada e mede cerca de noventa espaços de largura por trezentos de comprimento, da praia à igreja paroquial, onde termina. A igreja, dedicada a Nossa Senhora do Desterro, prejudica a regularidade da praça, pois não tiveram o cuidado de localizá-la a igual distância das duas fileiras de casas situadas em ambos os lados e deram de uma posição oblíqua em relação à praia."

O progresso do plano em 1808, subordinado ao mar, promove um "adensamento de habitações na parte oeste da cidade. São grupos de casa que na época marcaram as direções das ruas que se formavam. Aí o elemento diretor não era mais a praia, mas o sopé da colina em que as casas eram construídas." E em 1819 ocorre, "o progresso do adensamento da cidade no adensamento a leste da praça, na planície que facilita o traçado de rua paralela à praia." (Peluso Júnior, 1991, p.358).

Por ser, o território de Florianópolis composto pela Ilha principal, a Ilha de Santa Catarina e pela parte Continental, estas regiões somente foram conectadas uma a outra na década de 1920 com a construção da ponte Hercílio Luz, quando houve a vinculação Ilha-Continente.

Assumindo ares de cidade e a posição de capital do Estado, é no final da década de 1940, com o potencial representado pelas praias situadas na llha, que surgem os novos interesses de expansão das áreas residenciais, e a sua consequente ocupação em massa, em uma região de propriedades agrícolas (Mapa 01). 


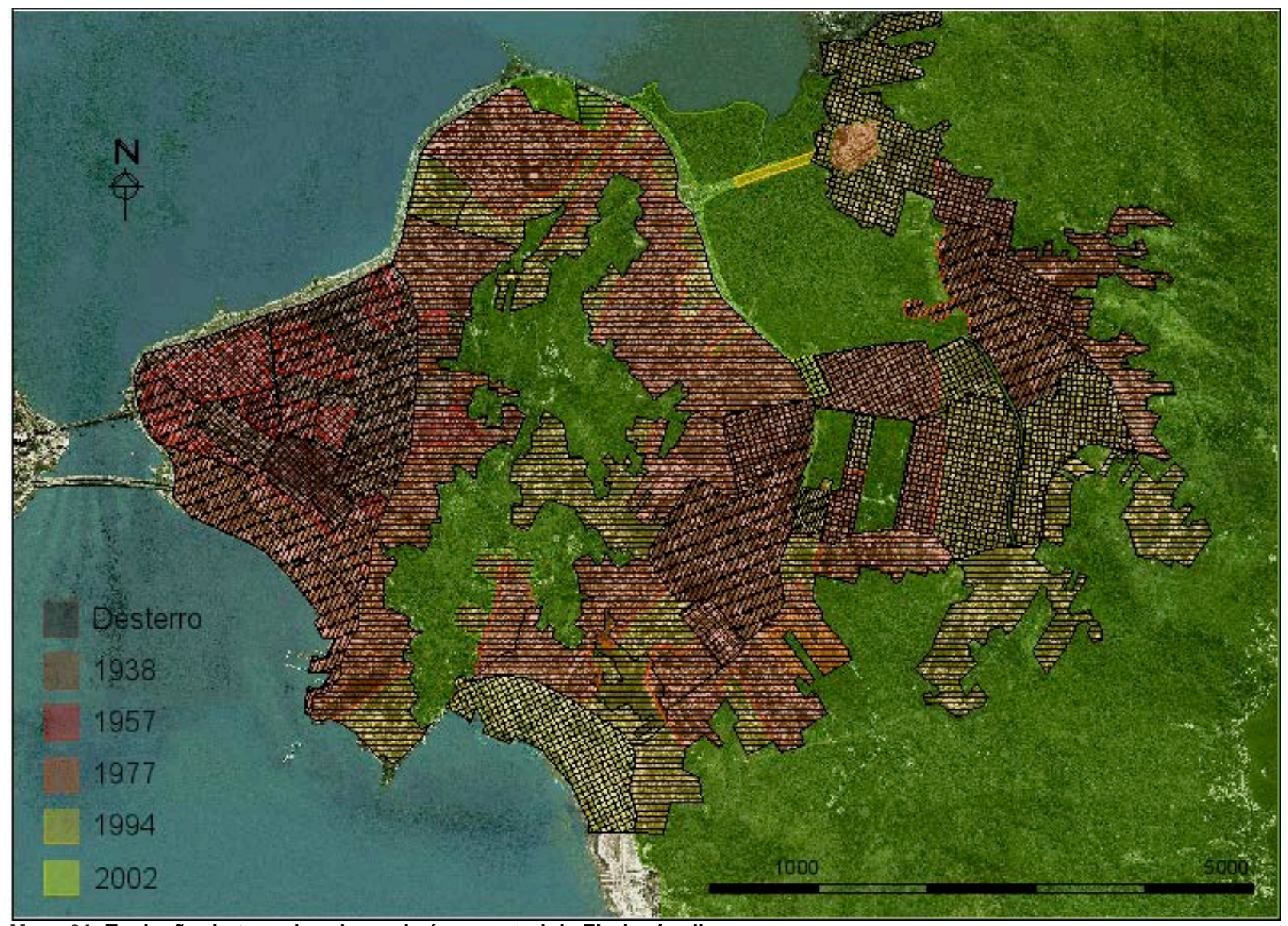

Mapa 01. Evolução do traçado urbano da área central de Florianópolis.

(Autoras, 2018).

Nessa ocupação, "a tendência é o xadrez, os ângulos retos são exceções. As quadras são irregulares. O seus elementos principais são a rua da praia, a praça central, a igreja e os primeiros arruamentos que se adaptaram ao relevo. Com essa complexidade de influência, o principal elemento é a praça da Igreja, pois que as ruas mais ou menos paralelas a praia devem chegar a ela." (Peluso Júnior, 1991, p.364).

O desenho do núcleo original da cidade, corresponde à antiga vila do Desterro (Mapa 01 e Figura 07), e se estrutura em uma malha bastante regular dividida pela praça $X V$, que com sua forma irregular, articula essas três porções no sentido de conformar um todo. "[...] A posição centralizada e articuladora da praça faz com que seja atravessada por praticamente todos os fluxos existentes. A regularidade da malha, que pouco diferencia os fluxos no seu interior, é quebrada pelo papel fundamental estabelecido pela praça. O Outro elemento diferenciador no contexto da malha uniforme é dado pela fachada litorânea, com toda a vida portuária ali existente." (Reis, 2012, p.98).

Reis (2012, p.99), ainda complementa, "[...] o gabarito relativamente uniforme, não ultrapassando os três pavimentos, a grande contiguidade da massa construída, a relação franca e direta entre o espaço interior das edificações e o espaço público (ruas, praças)", demonstram "a consolidação de um meio extremamente propício ao desenvolvimento de uma rica vida urbana". Assim, a nova malha, que com o passar dos anos foi se consolidando, "manteve a identidade morfológica do núcleo original da cidade e reforçou o seu caráter centralizador".

No século XX, a expansão urbana, abandonou esse plano, muito em função do sítio bastante descontínuo que a llha possui. Elevações (morros), dunas e massas d'água, que em sua totalidade atingem um percentual $73 \%{ }^{4}$ da área insular, representam as delimitações naturais do território. Essas delimitações naturais iniciais, são consideradas no trabalho, as fringes belts, ou cinturas periféricas (Mapa 02 - que mais tarde passam a

\footnotetext{
${ }^{4} \mathrm{Na}$ Ilha de Santa Catarina, atualmente existem 29 Espaços de Natureza Protegida (ENP), criados legalmente, alguns como Unidades de Conservação, representando 73\%, as Áreas de Preservação Permanente Municipal 23\% e uma unidade de conservação diferenciada, a Unidade de Conservação Ambiental Desterro (UCAD) com 4\%. (Ferreti, 2013, p.143).
} 
constituir parte da morfologia da área hoje considerada central) que impedem o crescimento urbano da região central de Florianópolis e delimitam a sua expansão.

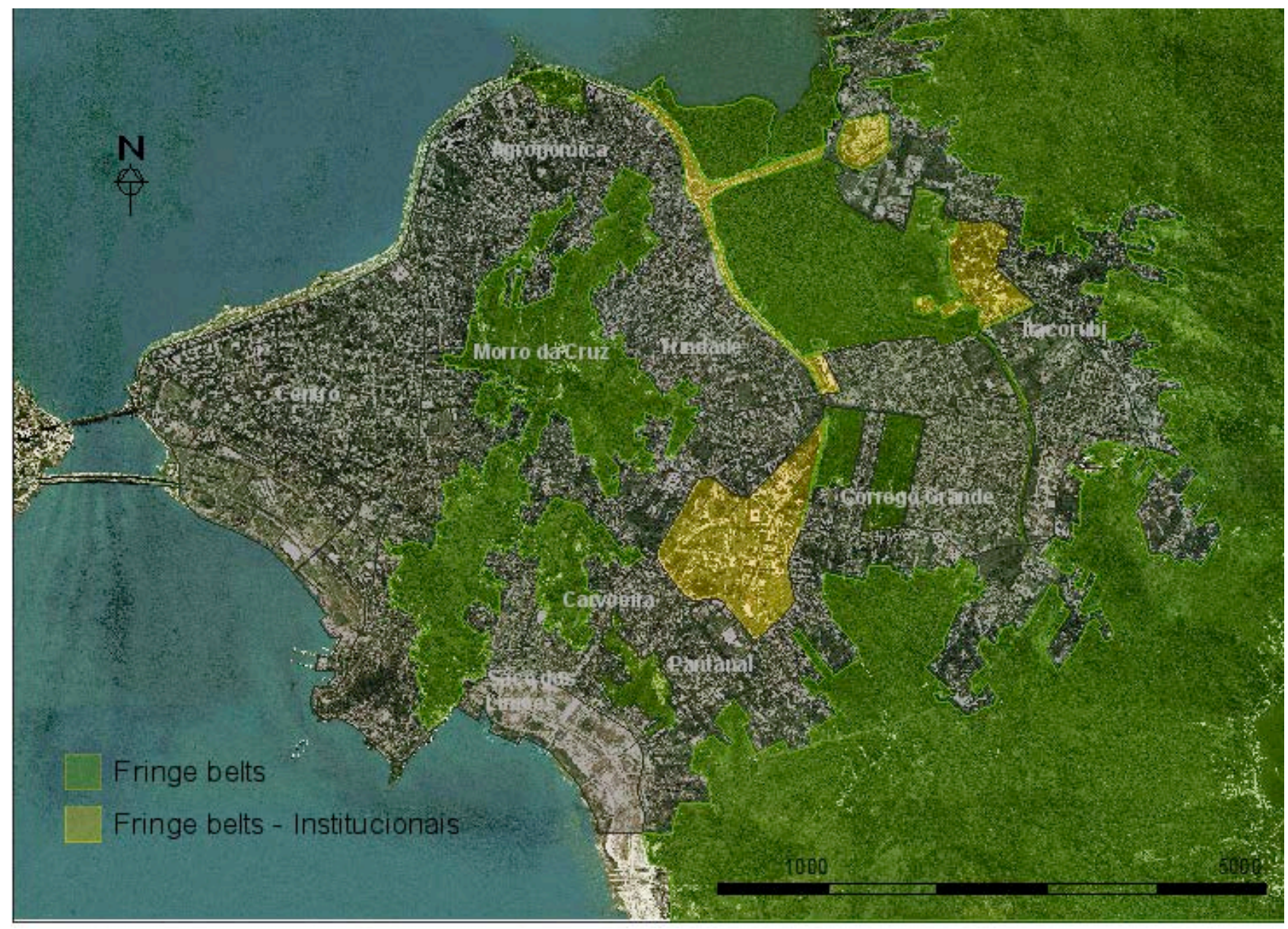

Mapa 02. Fringes belts, ou cinturas periféricas da área central de Florianópolis.

(Autoras, 2018).

"Cada uma dessas localidades possui limitações bastante fortes, estabelecidos por morros e mangue (Trindade, Córrego Grande, Saco Grande), morro e Baía Norte (Agronômica, Cacupé), mangue e Baía sul (Saco dos Limões, Costeira do Pirajubaé), morro e morro (Pantanal). A superfície ocupada abrange terrenos planos e de encosta. A ocupação das encostas que apresentam forte declividade é generalizada, situação que se radicaliza na costeira, com certeza um dos casos mais dramáticos na llha, com as ruas, todas perpendiculares as curvas de nível, em muitas localidades substituídas por escadas." (Reis, 2012, p.139). Essas localidades podem ser identificadas no Mapa 02.

Em função das características do sítio, muitas áreas de encostas, banhados e dunas, foram consideradas como inaptas para o uso agrícola. Cecca apud Reis (2012, p.84), "entende o espaço comunal como uma realidade ainda mais ampla, que engloba não apenas as terras, mas também os mangues, lagos, estuários e Costa marinha da llha.". Estas, mantidas em sua forma natural, foram destinadas a propriedades comunais, com fins comunitários.

O que se percebe, é que a produção do espaço urbano foi se acomodando em áreas possíveis de se habitar. Dessa forma, o parcelamento do solo da llha foi demarcado basicamente nos lotes cultiváveis, que tinham terrenos mais propícios, tanto para as atividades agrícolas quanto para os assentamentos, porém de acordo com as orientações previstas na Provisão Régia, "grandes porções insulares foram divididas em minifúndios", muitos deles resultantes em "propriedades bastante diminutas, as quais tiveram sua área diminuída ainda mais no correr do tempo com a prática do sobreparcelamento, quando da divisão das terras entre os herdeiros", o que ocasionou posteriormente, na própria "decadência da produção agrícola estabelecida na Ilha de Santa Catarina". (Reis, 2012, p.80).

Para Peluso Júnior (1981, p.13), "as pequenas propriedades rurais nos arredores da cidade pertenciam a pessoas abastadas que as tinham como refúgio, mas em parte também agricultores que delas vivem." Nesse 
processo, "a cidade assim não teve facilidade para se expandir, porque os ricos não queriam se desfazer dessas áreas de recreação e os agricultores relutavam em trocar o seu meio de vida agrícola pelo citadino. O plano urbano, então, era crescido quando a chácara se dividia por partilha hereditária ou quando o proprietário optava pelo lucro que ele proporcionaria a divisão da terra." (Peluso Júnior, 1981, p.13).

O estudo do plano urbano de Florianópolis foi baseado nas análises desenvolvidas por Conzen em Alnwick, a partir da leitura bidimensional das ruas e parcelas (sem considerar o tecido edificado nem os usos do solo), entre o período de 1938 até 2002. Entendendo que a "região morfológica é uma área que tem uma unidade em relação à sua forma que a distingue das áreas envolventes" (já citada anteriormente), foram identificadas na área central de Florianópolis, três tipos básicos de parcelamento identificados nas 36 regiões morfológicas (Mapa 03), em cinco ordens hierárquicas (Mapa 04).

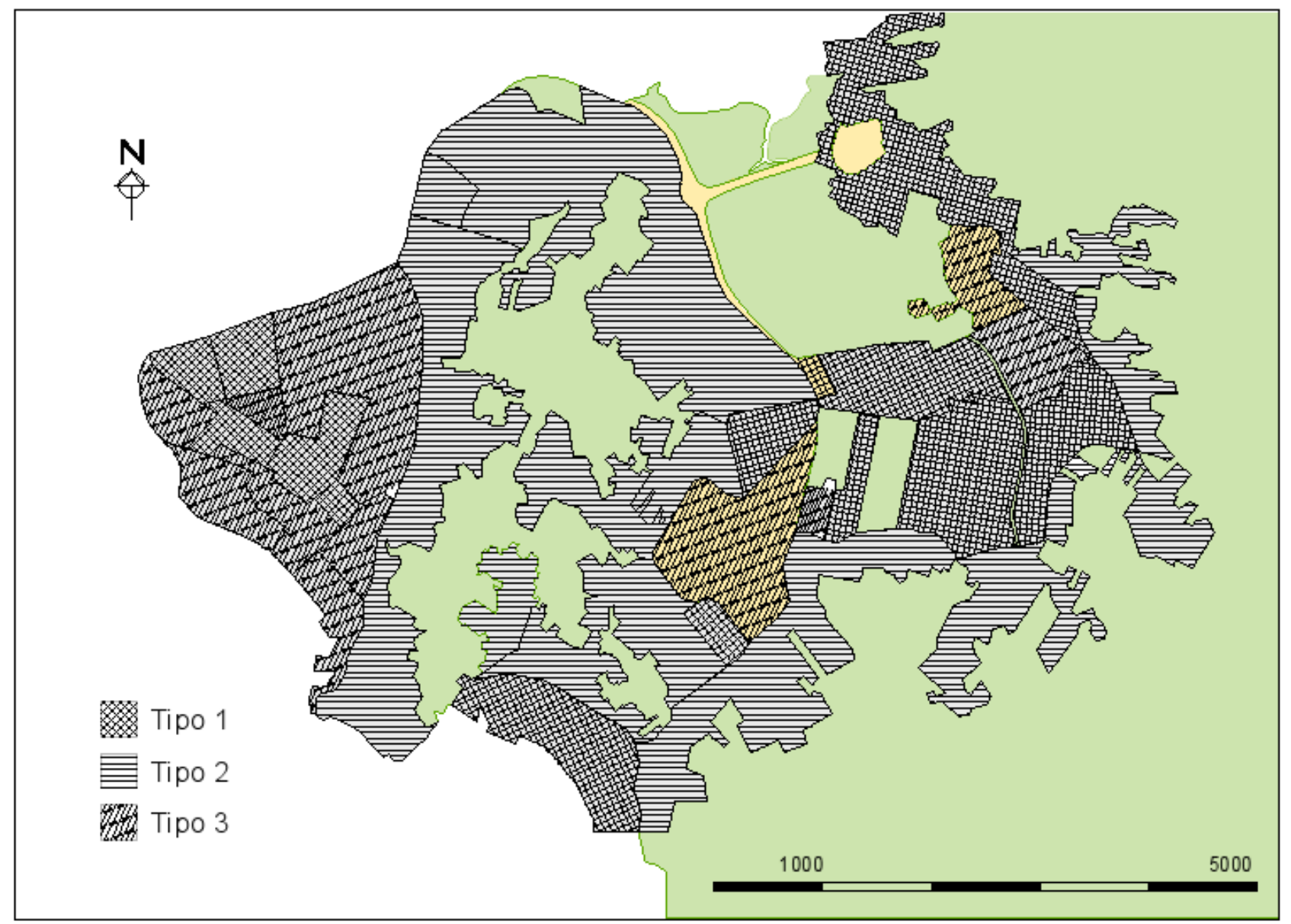

Mapa 03. Regiões morfológicas da área central de Florianópolis.

(Autoras, 2018). 


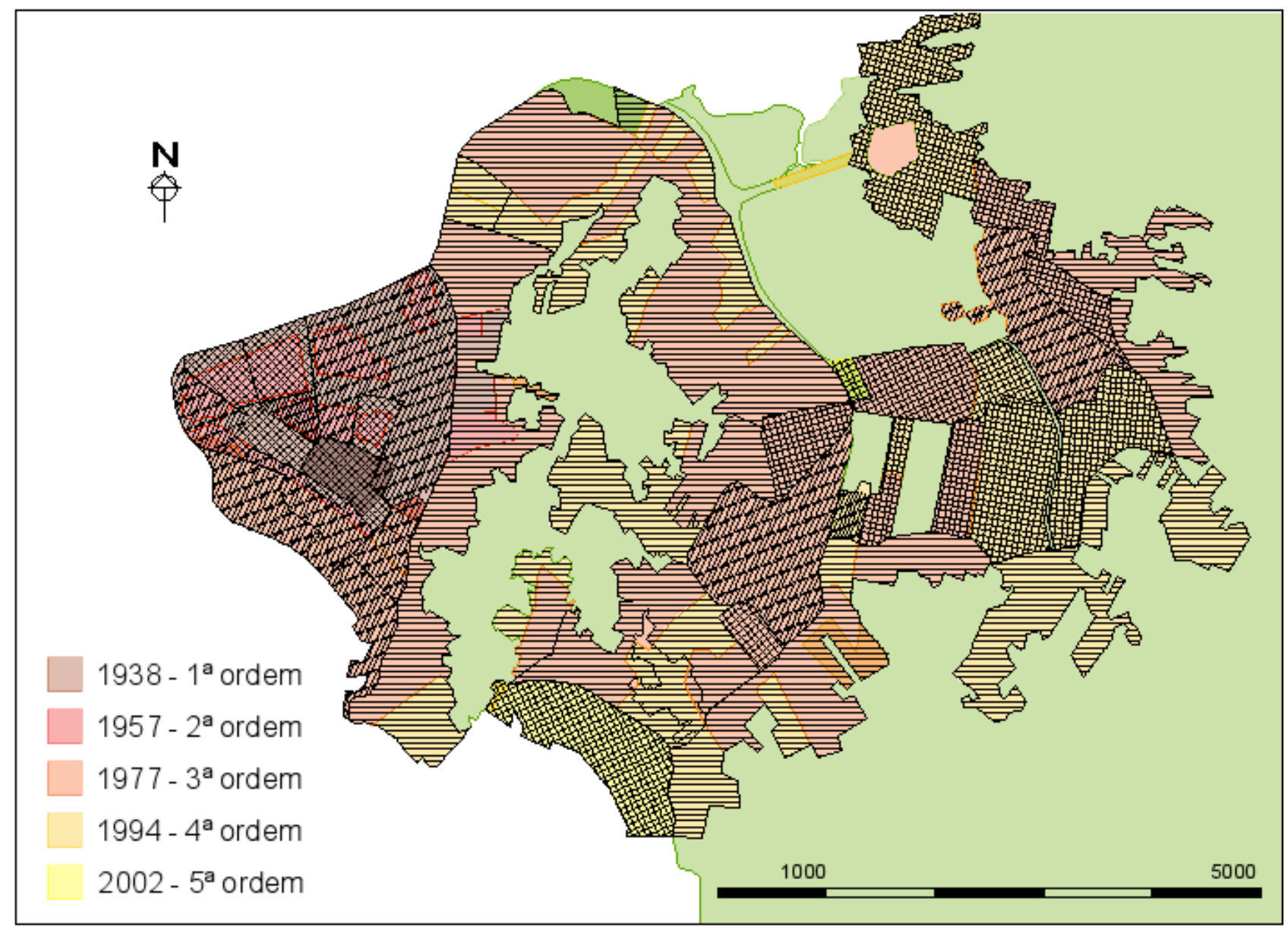

Mapa 04. Limites e suas respectivas áreas.

(Autoras, 2018).

Dessa forma, ao confrontar o mapa das regiões morfológicas com as respectivas ordens identificadas, temse a definição das unidades de plano em um período de 65 anos de ocupação do espaço urbano (Mapa 05), classificados da seguinte forma: em 1938 (9 unidades de plano); em 1957 (10 unidades de plano); em 1977 (23 unidades de plano); em 1994 (26 unidades de plano) e 2002 (2 unidades de plano). Estas unidades representam as regiões morfológicas identificadas em cada período levantado.

"O território da llha de Santa Catarina tem sido consideravelmente modificado, sobretudo a partir dos anos 1970." (Reis, 2012, p.136). E nestas transformações, os três tipos básicos de parcelamentos encontrados no estudo, Regular (R), Irregular (I) e Espinha de Peixe (EP) representam o parcelamento do solo encontrado na área central do território insular.

Parcelamento Regular (R): característico do núcleo original da cidade (1938), posteriormente em 1957 com a preenchimentos dos núcleos de quadras, é novamente utilizado em 1977, no parcelamento ordenado dos novos loteamentos que são implantados no bairro Santa Mônica ${ }^{5}$, estendido com as expansões que ocorreram em 1994 e 2002. O traçado regular é típico da influência portuguesa nas cidades.

Parcelamento Irregular (I): também típico do núcleo original, definido em função das bordas da llha e das características do relevo, já aparece no traçado de 1938, e da mesma forma que no parcelamento regular, faz o preenchimentos dos núcleos de quadras em 1957. Posteriormente a esse período, é igualmente visto em 1977, no parcelamento das áreas institucionais, na região da Trindade com a implantação do campus da Universidade Federal de Santa Catarina e, na região do Itacorubi, com a implantação da Universidade do Estado de Santa Catarina e alguns órgão estaduais.

Parcelamento em Espinha de Peixe (EP): característico dos caminhos rurais e demarcados em função da topografia da llha. "O caminho pré-existente transformado (estrada geral) e as vias laterais (ruas ou servidões)

${ }^{5}$ A identificação das localidades pode ser verificada no Mapa 02. 
constituem estruturas básicas do espaço público dessas localidades." (Reis, 2010). Este abrange grande parte do território, de forma tímida, nos parcelamentos de 1938 e 1957, mas que já é complementado na década de 1977 de forma bastante significativa, nas bordas do Morro da Cruz. Em 1994, a expansão preenche os vazios ainda existentes no Morro da Cruz, e inicia o mesmo processo no Itacorubi e Córrego Grande.

Em função das características de sítio, os traçados irregulares, mas principalmente o parcelamento em espinha de peixe, fizeram com que os lotes fossem "demarcados a partir da orla do mar, baías e lagoas, ou dos caminhos e trilhas pré-existentes." (Reis, 2012, p.81). Nestes, "os lotes tem aí registrados somente sua testada, a frente aos caminhos, que foi cada vez mais valorizada no correr do tempo com a construção das moradias, bem como com o sobreparcelamento, sempre realizado no sentido longitudinal ao lote, perpendicular ao caminho." (Reis, 2012, p.82). Reis (2012, p.137), ainda complementa, que com o passar dos tempos, a "expansão marcou a substituição das quadras regulares, características do centro da cidade, pelo traçado irregular gerado no sistema de propriedades agrícolas da área."

Nesse processo, Barbosa (2004) coloca que "historicamente, as cidades tradicionais construídas no Brasil possuem características morfológicas na tradição urbana portuguesa. Podemos citar características de destaque, como a lógica das suas localizações, nas especificidades topográficas dos sítios em geral, na relação que estabelecem com o território, na estrutura global da cidade e nas suas principais linhas estruturantes, nas características do traçado, na estrutura de quarteirões e na estrutura de loteamento, nas suas características arquitetônicas, vernáculas ${ }^{6}[\ldots]$ ou eruditas ${ }^{7 "}$.

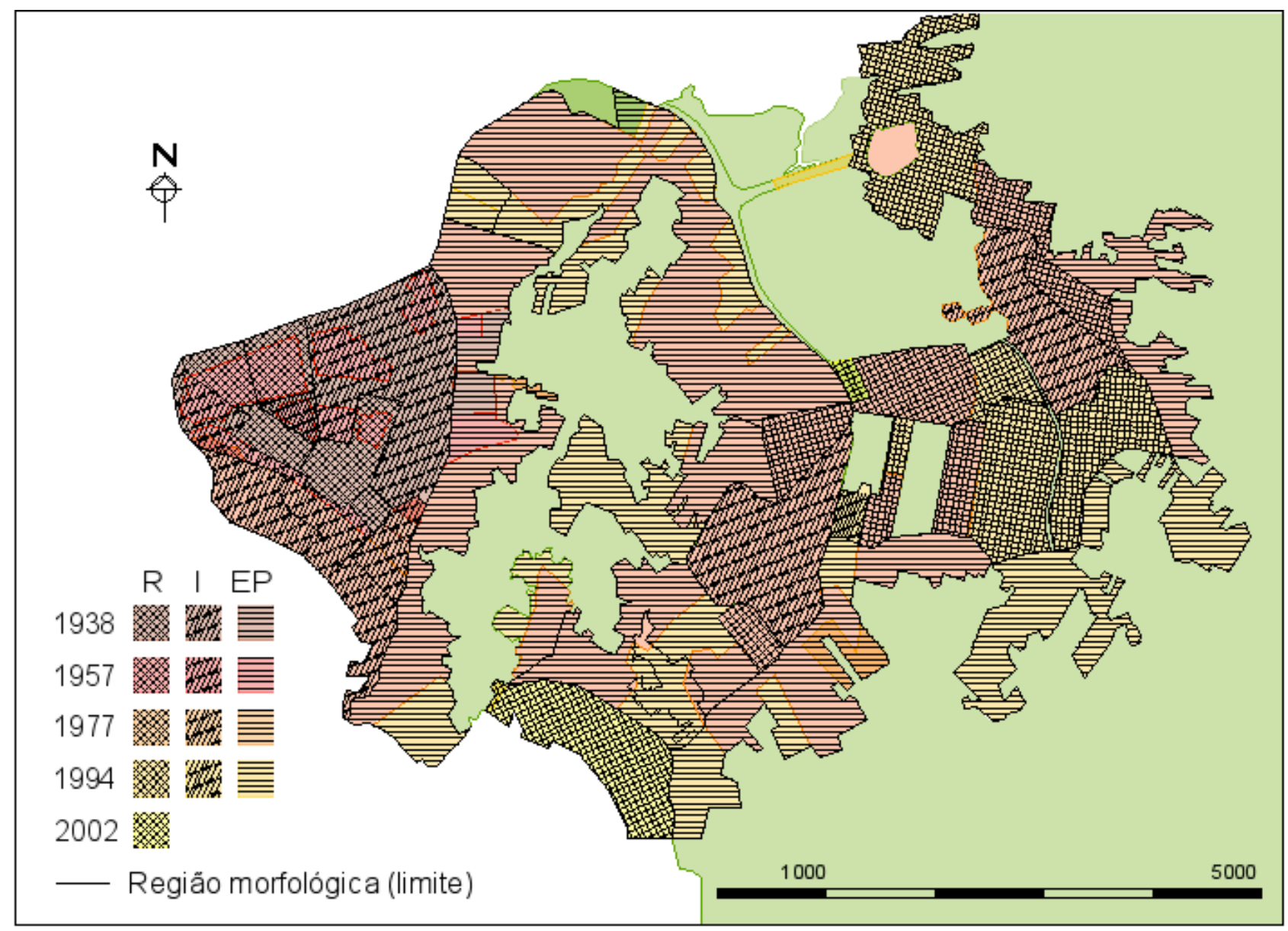

Mapa 05. Regiões morfológicas da área central de Florianópolis.

(Autoras, 2018).

\footnotetext{
${ }^{6}$ A vertente vernácula do urbanismo portuguesa, tem como característica fundamental uma grande ligação ao território.

${ }^{7}$ A vertente erudita do urbanismo portuguesa, tem como característica fundamental basear-se, a maior parte das vezes, em sistemas ortogonais, e esta está presente em todas as épocas históricas.
} 
Para Teixeira (2000), "uma das principais características do urbanismo português é a sua capacidade de síntese destas duas vertentes, que pode ser observada ao longo da história. Não existem tipos puros de traçados nas cidades de origem portuguesa. A cidade portuguesa caracteriza-se sempre pela síntese destas duas concepções de espaço, harmonizando num todo coerente estas duas formas de fazer cidade, aí residindo, em grande parte, a sua especificidade."

Segundo Reis (2012, p. 189), o "parcelamento simples, é o crescimento espontâneo que se desenvolve aproveitando os caminhos coloniais e o parcelamento rural pré-existentes, estabelecendo novo traçado urbano em espinha de peixe; e o parcelamento ordenado, é o crescimento que gera assentamentos caracterizados por uma ordem formal sem nenhuma relação com a forma prévia de parcelamento rural."

Esse parcelamento, espinha de peixe (Figura 08), ocorreu de forma intensa, "na ocupação das encostas do Morro da Cruz, em que a diretriz dada pela forma do parcelamento agrícola ao crescimento urbano fica também claramente evidenciada. As ruas perpendiculares às curvas de nível, hoje existentes, denunciam a geometria das propriedades agrícolas que Ihes deram origem." (Reis, 2012, p.137).

"No crescimento para "trás do morro" (Figura 09), contornando as faces norte e sul do morro da cruz, se consolida o primeiro anel de bairros insulares da cidade: Agronômica, Trindade, Saco dos Limões, Costeira do Pirajubaé, Córrego Grande, Pantanal, Itacorubi, Saco Grande. Separados do centro pelo morro da cruz e entre si por manguezais e outros morros, as áreas ocupadas pelo parcelamento simples correspondem exatamente aquelas outrora ocupadas por agricultura. [...] A geometria resultante, em "espinha de peixe", com o antigo caminho rural estruturando vias perpendiculares, é comum a todos eles, como você está também no restante das áreas do interior insular." (Reis, 2012, p.138).

"O caráter funcional diferenciado dessa porção da cidade, dada pela concentração de atividades institucionais e de moradias permanentes, não impediu que as formas de incorporação das terras rurais à cidade e as formas de crescimento urbano sejam bastante semelhantes àquelas que ocorrerão no restante do território insular. O processo de parcelamento simples, com a divisão das propriedades rurais e a transformação dos caminhos em vias de duradouras dos bairros, se repetirá de forma bastante semelhante [...]" (Reis, 2012, p.141) nas demais regiões da llha.

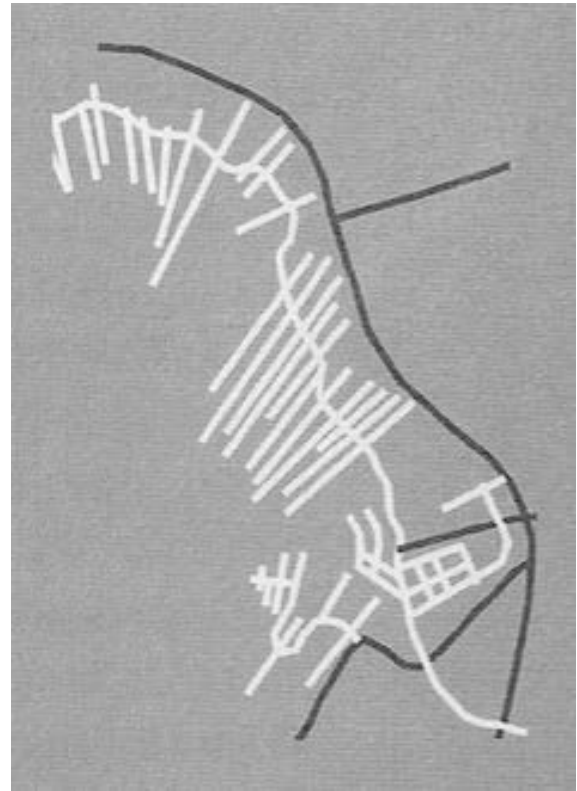

Figura 08. Estradas gerais e servidões Trindade

(Reis, 2012, p.235).

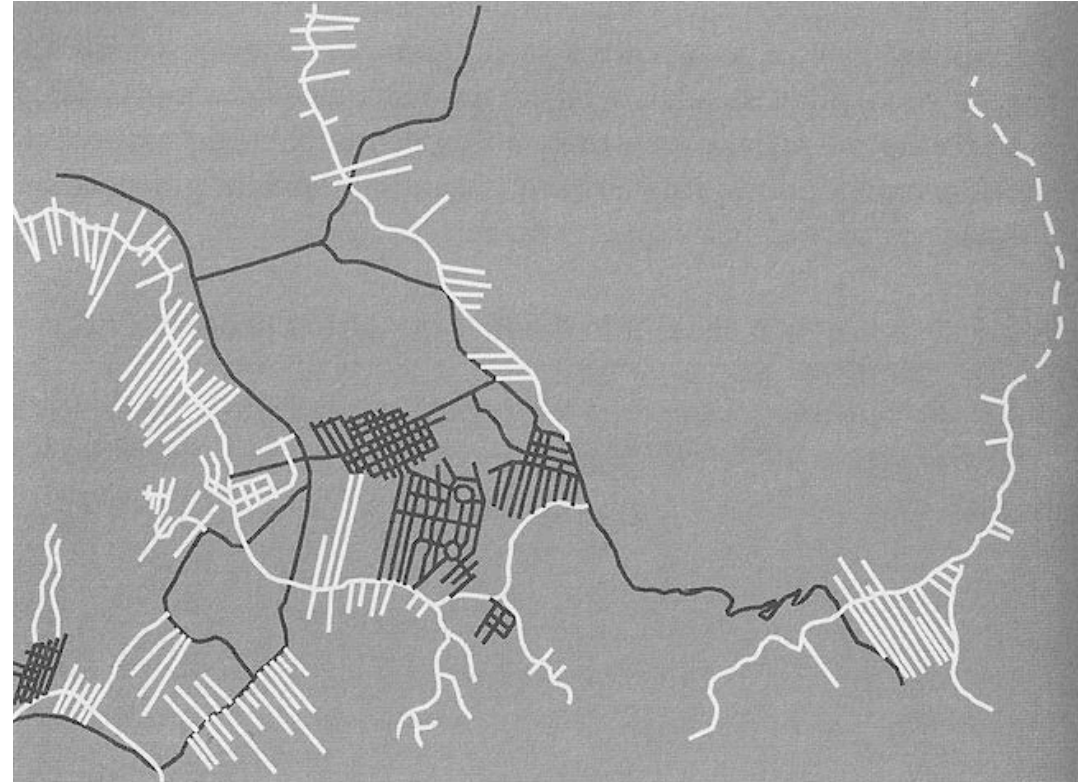

Figura 09. Parcelamento ordenado (em preto) e assentamentos pré-existentes (em branco) - Bacia do Itacorubi (Reis, 2012, p.246).

Estes parcelamentos são originados a partir do sistema viário da llha, e "hoje, as vias principais, que estruturam muito dos bairros da cidade, assim como muitas localidades da llha, foram constituídas a partir do sucessivo desenvolvimento desses caminhos. Circular aí significa encontrar-se com vários vestígios da história da ocupação da llha, nas edificações e propriedades agrícolas remanescentes, bem como nas novas formas urbanas condicionadas pela estrutura fundiária." (Reis, 2012, p.77). 
Por fazer a conexão entre os diversos assentamentos implantados, as estradas gerais (como são até hoje conhecidas) foram incorporando novas funções e significados. Com a construção primeiramente de moradias, foram adquirindo com o passar do tempo novas atividades comerciais e comunitárias, consolidando-se assim ocupações com características urbanas, que explicam a estrutura atual do plano da cidade de Florianópolis, a partir da análise do seu desenvolvimento.

Barbosa (2004), ainda complementa "que a tradição vernácula tem como uma de suas características mais importantes, a relação com o território, que pode ser observada na escolha de localizações, nas características específicas dos sítios selecionados para a sua fundação, na escolha de locais proeminentes para a implantação de edifícios institucionais, na definição das principais vias estruturantes, que se inserem simultaneamente numa lógica territorial e urbana que as articulam, na estruturação global da cidade e definição do seu traçado, assim como no desenvolvimento de espaços urbanos com características formais específicas."

\section{CONSIDERAÇÕES FINAIS}

Nesses processos de transformações e mudanças de uso do território, relacionadas diretamente ao estabelecimento do traçado das cidades, definem-se e relacionam-se em paralelo, os espaços públicos e privados, as parcelas e as vias públicas, as redes de infraestrutura e o modo de relação entre as distintas tramas urbanas.

A partir desta abordagem, definida por Conzen, foi possível identificar o processo de desenvolvimento do território da região central da llha de Florianópolis, juntamente com os elementos urbanos que oferecem o menor grau de transformação em sua estrutura, o plano urbano em si, e as ruas, em função de serem estas as que permanecem por mais tempo na estrutura urbana e são as mais custosas em um processo evolutivo de modificação e readequação do espaço urbano.

O modelo de ocupação territorial estabelecido em Florianópolis sofreu inúmeras adaptações desde a sua colonização, até com o posterior desenvolvimento das povoações formadas, muito em função das características físicas do sitio em que se encontra. Porém, "sua espacialização no território insular engendrou a estrutura territorial que perdurará, pelo menos em suas características principais, até o presente [...]. (Reis, 2012, p.65). Desta forma, esta pesquisa, reforça a importância de se considerar as questões históricas como forma de representação da vida e da cultura de determinada região, registradas no seus arranjos físicos e nas áreas edificadas da população ali enraizada.

\section{BIBLIOGRAFIA}

BARBOSA, A. A. (2004). Cidade e habitação em Minas nos séculos XVIII - XIX. NOMADS: USP, Disciplina SAP 5846 - Habitação, metrópoles, modos de vida.

CAPEL, H. (2002). La morfologia de las ciudades. Barcelona: Ediciones del Serbal.

CARLOS, A. F. A. (1994). A (re)produção do espaço urbano. São Paulo: Editora da Universidade de São Paulo.

CONZEN, M. P. (ed.). (2004). Thinking About Urban Form: Papers on Urban Morphology, 1932-1998. Peter Lang: Oxford.

CONZEN, M. R. G. (1960). Alnwick, Northumberland: a study in town-plan analysis. London: George Philip.

COSTA, S. A. P.; NETTO, M. M. G. (2015). Fundamentos de Morfologia Urbana. Belo Horizonte: C/Arte.

FITZ, P. R. (2008). Geoprocessamento Sem Complicação. São Paulo: Oficina de Textos.

OLIVEIRA, V. (ed.). (2018). Diferentes abordagens em morfologia urbana. Contributos luso-brasileiros. Porto: Urban Forms books. . (2016). Morfologia urbana: diferentes abordagens. Revista de Morfologia Urbana (Porto), 02, 65-84. 
PELUSO JÚNIOR, V. A. (1991). Estudos de geografia urbana de Santa Catarina. Florianópolis: Secretaria de Estado da Cultura e do Esporte: Ed. da UFSC.

REIS, A. F. (2012). Ilha de Santa Catarina: permanências e transformações. Florianópolis: Ed. da UFSC.

SANTOS, M. (2014 [1985]). Espaço e Método. 5a ed. São Paulo: Editora da Universidade de São Paulo.

SAINT-HILARIE, A. (1978). Viagem a Curitiba e Província de Santa Catarina. Belo Horizonte/São Paulo: Itatiaia/EDUSP.

SOLÀ-MORALES, M. (1997). Las formas de crecimiento urbano. Barcelona: Edicions UPC.

SPOSITO, M. E. B. (2016). A produção do espaço urbano: Escalas, diferenças e desigualdades socioespaciais. In: CARLOS, Ana Fani Alessandri; SOUZA, Marcelo Lopes de; SPOSITO, Maria Encarnação Beltrão. A produção do Espaço Urbano (123-145). São Paulo: Contexto.

TEIXEIRA, M. C. (2000). Os Modelos Urbanos Portugueses da Cidade Brasileira. Colóquio A Construção do Brasil Urbano, Arrábida, Lisboa.

WHITEHAND, J. W. R. (2007). Conzenian Urban Morphology and Urban Landscapes. 6th International Space Syntax Symposium, İstanbul, 12-15 Junho (Online).

\section{Fontes eletrônicas:}

http://geo.pmf.sc.gov.br (Consulta: 10/06/2017).

http://roberto-menezes.blogspot.com.br/2011/01/curiosidades-respeito-da-ilha-de-santa.html (Consulta: 18 /02/2018). 